\title{
Developmental Expression of Endothelin Receptors in Postnatal Swine Mesenteric Artery
}

\author{
BAOGEN Y. SU, KRISTINA M. REBER, AND CRAIG A. NANKERVIS
}

Division of Neonatology, Department of Pediatrics, The Ohio State University College of Medicine and Public Health and the Children's Research Institute, Children's Hospital, Columbus, Ohio, 43205, U.S.A.

\begin{tabular}{|c|c|}
\hline \multicolumn{2}{|c|}{ ABSTRACT } \\
\hline 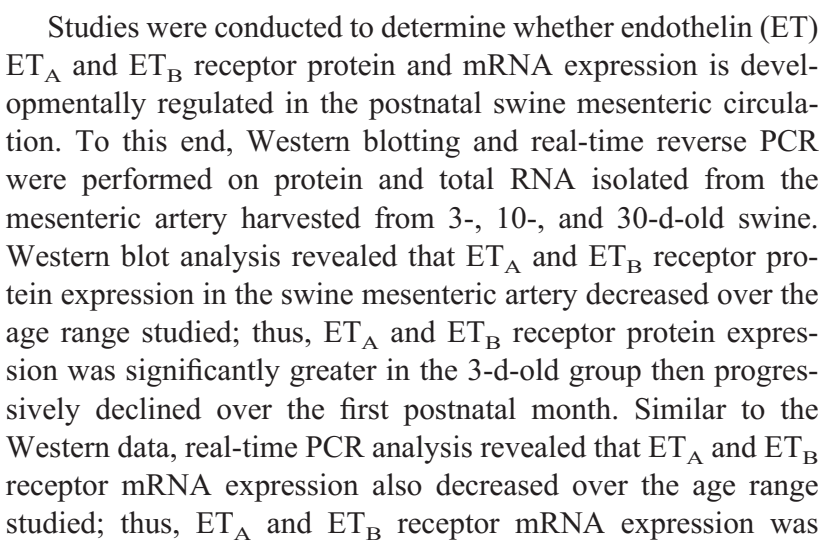 & $\begin{array}{l}\text { significantly greater in the 3-d-old group then progressively } \\
\text { declined over the first postnatal month. Immunohistochemistry } \\
\text { localized the } \mathrm{ET}_{\mathrm{A}} \text { receptor to the vascular smooth muscle and the } \\
\mathrm{ET}_{\mathrm{B}} \text { receptor to the endothelial cell layer. Additionally, we report } \\
\text { a partial cDNA sequence for the swine } \mathrm{ET}_{\mathrm{B}} \text { receptor. We con- } \\
\text { clude that } \mathrm{ET}_{\mathrm{A}} \text { and } \mathrm{ET}_{\mathrm{B}} \text { receptor protein and mRNA expression } \\
\text { is developmentally regulated in the postnatal swine mesenteric } \\
\text { artery, being expressed to a greater degree in younger animals. } \\
\text { (Pediatr Res 56: 359-365, 2004) } \\
\qquad \text { Abbreviations } \\
\text { ET, endothelin }_{\text {ET }_{\mathrm{A}} \text {, endothelin A receptor }} \\
\mathbf{E T}_{\mathbf{B}} \text {, endothelin B receptor }\end{array}$ \\
\hline
\end{tabular}

ET-1 is a potent vasoactive 21-amino acid peptide first isolated by Yanagisawa et al. (1) from the conditioned medium of cultured porcine aortic endothelial cells. ET-1 exerts its effects via the activation of at least two receptor subtypes, designated $\mathrm{ET}_{\mathrm{A}}$ and $\mathrm{ET}_{\mathrm{B}}(2-5)$. Both receptor subtypes are members of the seven-transmembrane-spanning, G proteincoupled superfamily of receptors whose activation leads to phospholipase $\mathrm{C}-$ mediated production of inositol triphosphate and diacylglycerol $(6,7)$. The $\mathrm{ET}_{\mathrm{A}}$ receptor is localized on vascular smooth muscle and its activation leads to vasoconstriction $(8,9)$. The $\mathrm{ET}_{\mathrm{B}}$ receptor is located on both endothelial cells and vascular smooth muscle. Activation of the endothelial cell $\mathrm{ET}_{\mathrm{B}}$ receptor leads to vasodilation via the production of nitric oxide (NO), whereas activation of the vascular smooth muscle $\mathrm{ET}_{\mathrm{B}}$ receptor leads to vasoconstriction $(5,10,11)$. Thus, the overall effect of ET- 1 on vascular tone is dependent on the proportion and location of $\mathrm{ET}_{\mathrm{A}}$ and $\mathrm{ET}_{\mathrm{B}}$ receptors within the vascular bed in question (12).

Received August 19, 2002; accepted March 15, 2004.

Correspondence: Craig A. Nankervis, M.D., Children's Hospital, 700 Children's Drive, Columbus, OH 43205, U.S.A.; e-mail: nankervc@pediatrics.ohio-state.edu

Supported by grant number DK58580 from the National Institute of Diabetes and Digestive and Kidney Diseases (K.M.R.).

DOI: 10.1203/01.PDR.0000134253.86014.B9
Previous work in this laboratory has demonstrated that the expression of $\mathrm{ET}_{\mathrm{A}}$ and $\mathrm{ET}_{\mathrm{B}}$ receptors may be developmentally regulated in the postnatal swine intestinal circulation. This possibility was first raised by a series of studies that used pharmacological probes to selectively block these receptors. Blockade of $\mathrm{ET}_{\mathrm{A}}$ receptors with $\mathrm{BQ} 610$ increased intestinal capillary perfusion and oxygen extraction in gut loops from 3-d-old but not 35-d-old swine, suggesting that $\mathrm{ET}_{\mathrm{A}}$ receptors are more abundant within the intestinal microcirculation of younger subjects (13). Blockade of $\mathrm{ET}_{\mathrm{B}}$ receptors with $\mathrm{BQ788}$ caused a leftward shift in the contractile dose-response curve for ET-1 in quiescent mesenteric artery rings from 3-d-old but not from 35-d-old subjects; also, stimulation of the $\mathrm{ET}_{\mathrm{B}}$ receptor with the selective agonist sarafotoxin $6 \mathrm{c}$ caused greater relaxation of precontracted mesenteric artery rings in 3-d-old but not 35 -d-old subjects $(14,15)$. These observations suggest that endothelial $\mathrm{ET}_{\mathrm{B}}$ receptors may also be more abundant in the mesenteric artery from younger subjects. Further evidence suggesting that expression of the $\mathrm{ET}_{\mathrm{A}}$ and endothelial $\mathrm{ET}_{\mathrm{B}}$ receptors in the postnatal intestinal circulation is developmentally regulated was provided by competitive binding assays, which demonstrated that both the $\mathrm{ET}_{\mathrm{A}}$ and the endothelial $\mathrm{ET}_{\mathrm{B}}$ receptor are expressed to a greater degree in younger animals compared with their older counterparts (16). 
Early postnatal life represents a critical stage in intestinal development. During this period, the intestine grows dramatically as it transitions from relative dormancy in utero to become the sole means of water and nutrient assimilation after parturition (17). Regulation of $\mathrm{ET}_{\mathrm{A}}$ and $\mathrm{ET}_{\mathrm{B}}$ receptor expression in the attendant intestinal circulation might play a critical role during this transition. Little is known about the expression pattern of these receptors in the intestinal circulation during early postnatal life. The goal of this study therefore was to determine the expression of $\mathrm{ET}_{\mathrm{A}}$ and $\mathrm{ET}_{\mathrm{B}}$ receptor protein and mRNA in postnatal swine mesenteric artery during early postnatal life. Based on our previous observations, we hypothesized that $\mathrm{ET}_{\mathrm{A}}$ and $\mathrm{ET}_{\mathrm{B}}$ receptor protein and $\mathrm{mRNA}$ expression are developmentally regulated; specifically, that the newborn swine superior mesenteric artery expresses $\mathrm{ET}_{\mathrm{A}}$ and $\mathrm{ET}_{\mathrm{B}}$ receptor protein and mRNA to a greater degree than that noted in their older counterparts. To test this hypothesis, Western blot analysis and real-time $\mathrm{PCR}$ for the $\mathrm{ET}_{\mathrm{A}}$ and $\mathrm{ET}_{\mathrm{B}}$ receptor were carried out on protein and total RNA isolated from the mesenteric arteries of 3-, 10-, and 30-d-old swine. Immunohistochemistry was performed on sections of whole mesenteric artery from the same age groups to localize the $\mathrm{ET}_{\mathrm{A}}$ and $\mathrm{ET}_{\mathrm{B}}$ receptors. Additionally, we report a partial cDNA sequence for the swine $\mathrm{ET}_{\mathrm{B}}$ receptor.

\section{METHODS}

Care and handling of experimental animals. Studies were conducted using farm-bred swine of either sex obtained on the day of use $(18,19)$. Three age groups were studied: 3,10 , and $30 \mathrm{~d}$ old, and all subjects were studied on that postnatal day; age ranges were not used. Subjects from each age group were allowed access to the age-appropriate diet (sow's milk for the 3 - and 10-d-old group, chow for the 30-d-old group) until transport to the laboratory and were studied within $2 \mathrm{~h}$ of their arrival. Anesthesia was induced with telezol $(6 \mathrm{mg} / \mathrm{kg}$ i.m.) and xylazine $(7.5 \mathrm{mg} / \mathrm{kg}$ i.m.) and maintained with sodium pentobarbital ( $5 \mathrm{mg} / \mathrm{kg} / \mathrm{h}$ i.v.). After tissue removal, animals were killed with an overdose of pentobarbital $(50 \mathrm{mg} / \mathrm{kg}$ i.v.) while still anesthetized. All animal care was provided in accordance with The Guide for the Care and Use of Laboratory Animals [DHHS Publication No. (National Institutes of Health) 85-23, Revised 1985, Office of Science and Health Reports, Bethesda, MD 20892]. All experimental protocols were approved and monitored by the Institutional Animal Care and Use Committee of the Children's Research Institute. All work involving live animals was carried out in the Children's Research Institute Vivarium, an Association for Assessment and Accreditation of Laboratory Animal Care International-approved facility under the supervision of a full-time veterinarian.

Protein isolation for Western blot analysis. The entire mesenteric artery was removed en bloc, snap frozen in liquid nitrogen, and stored at $-80^{\circ} \mathrm{C}$ until use. The frozen vessel segments were pulverized to a fine powder using a mortar and pestle on dry ice and were suspended in homogenization buffer (20 mM MOPS, 1\% Triton, 4\% SDS, 10\% glycerol, $5.5 \mathrm{mM}$ leupeptin, $5.5 \mathrm{mM}$ pepstatin, $200 \mathrm{KIU}$ aprotinin, $1 \mathrm{mM}$ $\mathrm{Na}_{3} \mathrm{VO}_{4}, 10 \mathrm{mM} \mathrm{NaF}, 100 \mu \mathrm{M} \mathrm{ZnCl}_{2}, 20 \mathrm{mM}$ B-glycerophos- phate, an $20 \mu \mathrm{M}$ phenylmethylsulfonyl fluoride). The samples were mixed by repeated pipetting, placed on ice for $10 \mathrm{~min}$, and finally centrifuged at $10,000 \mathrm{rpm}$ for $5 \mathrm{~min}$ at room temperature to pellet any debris. The supernatant was collected and a small aliquot was used to determine protein concentration using the bicinchoninic acid (BCA) protein assay (Pierce Chemical, Rockford, IL, U.S.A.).

Western blot analysis. For Western blot analysis, $10 \mu \mathrm{g}$ of protein was resolved on a $10 \%$ denaturing polyacrylamide gel (SDS-PAGE) and then electrophoretically transferred overnight to polyvinylidene difluoride membranes (Immuno-Blot PVDF Membrane, Bio-Rad, Hercules, CA, U.S.A.). The membranes were blocked with $5 \%$ nonfat milk in Tris-buffered saline containing $0.1 \%$ Tween- 20 . The membranes were then incubated for $1 \mathrm{~h}$ at room temperature in a shaker with a 1:200 dilution of either rabbit anti-ET $\mathrm{E}_{\mathrm{A}}$ receptor antibody or rabbit anti-ET ${ }_{\mathrm{B}}$ receptor antibody (Alomone Labs, Jerusalem, Israel). After incubation with primary antibody, the membranes were washed with Tris-buffered saline containing $0.1 \%$ Tween- 20 and then incubated with a 1:2000 dilution of anti-rabbit IgGhorseradish peroxidase conjugate. The membranes were washed with Tris-buffered saline containing $0.1 \%$ Tween-20 and the protein bands of interest were detected via chemiluminescence (ECL, Amersham Pharmacia Biotech, Piscataway, NJ, U.S.A.). All samples from each age group were resolved simultaneously on a single gel. Each blot was then stripped and incubated with $1^{\circ}$ antibody to $\beta$-actin to correct for sample loading. Previous studies in our laboratory revealed that $\beta$-actin expression within mesenteric artery does not change over the age range examined in this study. The bands of interest were quantified using scanning densitometry (Model GS-700 Imaging Densitometer, Bio-Rad), normalized to the 3-d-old group, and the relative expression of $\mathrm{ET}_{\mathrm{A}}, \mathrm{ET}_{\mathrm{B}}$ and $\beta$-actin protein were then calculated.

$R N A$ isolation for partial cloning of the swine $E T_{B}$ receptor and real-time PCR. The tissue of interest was removed, cut into small segments $(<0.5 \mathrm{~cm}$ in any dimension), and immediately placed in RNA storage solution (RNAlater, Ambion, Austin, TX, U.S.A.). The tissue segments were placed at $4^{\circ} \mathrm{C}$ overnight and then stored at $-80^{\circ} \mathrm{C}$ until final preparation per the manufacturer's instructions. The segments were removed from the storage solution, weighed, and total RNA extracted using a commercially available kit (RNAwiz, Ambion) before spectrophotometric determination of total RNA concentration.

Partial clone of the swine $\boldsymbol{E T}_{B}$ receptor. To design primers and a probe for real-time PCR for the $\mathrm{ET}_{\mathrm{B}}$ receptor, it was necessary to clone this sequence inasmuch as the cDNA sequence for the swine $\mathrm{ET}_{\mathrm{B}}$ receptor has not been reported. To this end, total RNA was isolated from swine liver and was used to obtain poly (A) RNA using a Poly (A) Pure mRNA purification kit (Ambion). A pool of enriched full-length doublestranded cDNA was generated using the SMART technique from the SMART cDNA Library Construction Kit (CLONTECH, Palo Alto, CA, U.S.A.). Briefly, the purified poly (A) RNA was used in the first-strand synthesis using a modified oligo (dT) primer (CDSIII/3'PCR Primer). During the reverse transcription reaction, the PowerScript reverse transcriptase adds a few additional nucleotides, primarily deoxycytidine, to 
the $3^{\prime}$ end of the cDNA, which compliment to the oligo (G)s at the $3^{\prime}$ end SMART IV oligonucleotide. Enriched doublestranded cDNA were then generated by a follow-up PCR step using these two oligonucleotides (CDSIII and SMART IV). For partial cloning of the swine $\mathrm{ET}_{\mathrm{B}} \mathrm{cDNA}$ sequence, two PCR primers $\left(\mathrm{ET}_{\mathrm{B}}\right.$ sense: 5'-CAAAATGGACAGCAGTAGAAA-3' and $\mathrm{ET}_{\mathrm{B}}$ antisense 5'-GACTTAAAGCAGTTTTTGAATCT3 ') were designed based on the consensus sequences of cDNA homologues of other species (20). These primers generated a 552-bp fragment. The amplified PCR product was subsequently cloned into a pCR4-TOPO plasmid vector and the insert of one positive clone was verified by sequencing in the Children's Research Institute core laboratory using an automated DNA sequencer. Sequence information is available in GenBank (accession number AY583500).

Real-time PCR. To quantify expression of $\mathrm{ET}_{\mathrm{A}}$ and $\mathrm{ET}_{\mathrm{B}}$ mRNA, we chose real-time PCR methodology, as this technique provides the most precise means of mRNA quantification when compared with Northern blotting or RNA protection assays. Two micrograms of total RNA isolated from the swine mesenteric artery was treated with DNase I before reverse transcription to cDNA using a commercially available kit (SuperScript First-Strand Synthesis System, Invitrogen, Carlsbad, CA, U.S.A.). The Primer 3 software package (Steve Rozen and Helen J. Skaletsky, Whitehand Institute, MIT Center for Genome Research) was used to generate real-time PCR primers and fluorescence-tagged probes for the $\mathrm{ET}_{\mathrm{A}}$ and $\mathrm{ET}_{\mathrm{B}}$ receptor. The $\mathrm{ET}_{\mathrm{A}}$ primers and probe were designed based on the published cDNA sequence for the swine $\mathrm{ET}_{\mathrm{A}}$ receptor (GenBank accession number S80652), whereas those for the $\mathrm{ET}_{\mathrm{B}}$ receptor were designed based on the 552-bp partial cDNA sequence for the swine $\mathrm{ET}_{\mathrm{B}}$ receptor generated in our laboratory. The real-time PCR primers and probe for the $\mathrm{ET}_{\mathrm{A}}$ receptor flanked a 130-bp fragment from bp 608 to bp 737. The real-time PCR primers and probe for the $\mathrm{ET}_{\mathrm{B}}$ receptor were nested within the PCR primers used for the partial cloning of the $\mathrm{ET}_{\mathrm{B}}$ receptor and amplified a 76-bp fragment within this 552-bp partial sequence. The sequences for the real-time PCR primers and probe for the $\mathrm{ET}_{\mathrm{A}}$ and $\mathrm{ET}_{\mathrm{B}}$ receptor are presented in Table 1. As it has been used as a loading standard in other studies dealing with the developmental expression of other proteins, 18S ribosomal RNA served as an internal control. Preliminary work in our laboratory has indicated stability of the $18 \mathrm{~S}$ ribosomal RNA signal during the postnatal time period under study. The real-time PCR primers and fluorescencetagged probe for $18 \mathrm{~S}$ ribosomal RNA controls are commercially available and were purchased directly from the manufacturer (PerkinElmer Life Science, Boston, MA, U.S.A.). The different fluorescent labeling of the probes allows simultaneous determination of a target gene $\left(\mathrm{ET}_{\mathrm{A}}\right.$ or $\left.\mathrm{ET}_{\mathrm{B}}\right)$ and the internal control (18S ribosomal RNA) mRNA abundance in a real-time fashion. A typical $25-\mu \mathrm{L}$ real-time reaction for the $\mathrm{ET}_{\mathrm{A}}$ receptor contained $1 / 20$ of RT reaction cDNA, $200 \mathrm{nM}$ and $100 \mathrm{nM}$ for $\mathrm{ET}_{\mathrm{A}}$ primers and probe, $100 \mathrm{nM}$ and $50 \mathrm{nM}$ for $18 \mathrm{~S}$ ribosomal RNA primers and probe, and real-time PCR master buffer. The real-time reaction for the $\mathrm{ET}_{\mathrm{B}}$ receptor was identical to that for the $\mathrm{ET}_{\mathrm{A}}$ receptor except that $\mathrm{ET}_{\mathrm{B}}$ primers and probe were used. PCR reactions were carried out in an ABI Prism 7700 Detection System (PerkinElmer Life Science) under the following conditions: $50^{\circ} \mathrm{C}$ for $2 \mathrm{~min}, 95^{\circ} \mathrm{C}$ for $10 \mathrm{~min}$ followed by 40 cycles at $95^{\circ} \mathrm{C}$ for $15 \mathrm{~s}$ and $60^{\circ} \mathrm{C}$ for $1 \mathrm{~min}$. All PCR reactions were run in duplicate and the results were analyzed using the Sequence detector 1.6 program (PerkinElmer Life Science). The ABI Prism 7700 provides an amplification curve constructed by relating the fluorescence signal intensity $(\Delta \mathrm{Rn})$ to the PCR cycle number. The threshold cycle value $\left(\mathrm{C}_{\mathrm{t}}\right)$ corresponds to the cycle at which an increase in $\Delta \mathrm{Rn}$ above background occurs and is thus a direct marker of the abundance of the mRNA in question. A lower $C_{t}$ value indicates a greater the abundance of the mRNA under study. The $C_{t}$ values obtained for the internal control (18S ribosomal RNA) were subtracted from the $C_{t}$ values obtained for the target gene mRNA in question $\left(\mathrm{ET}_{\mathrm{A}}\right.$ or $\left.\mathrm{ET}_{\mathrm{B}}\right)$, normalized to 3-d-old group, and the relative expression of $\mathrm{ET}_{\mathrm{A}}$ and $\mathrm{ET}_{\mathrm{B}}$ mRNA then calculated.

Immunohistochemistry. The entire mesenteric artery was removed en bloc and immediately immersed in $10 \%$ neutral buffered formalin then processed for paraffin sectioning by standard methods. Paraffin sections were mounted on glass slides and refrigerated until use. Slides were deparaffinized in xylene for $10 \mathrm{~min}$ then rehydrated in descending concentrations of ethanol $(100 \%, 90 \%, 70 \%, 5 \mathrm{~min}$ in each) and transferred to distilled water. Endogenous peroxidase activity was quenched by incubation with 3\% hydrogen peroxide for $15 \mathrm{~min}$ at room temperature. The sections were rinsed with distilled water for $2 \mathrm{~min}$ and digested with trypsin for $10 \mathrm{~min}$ at $37^{\circ} \mathrm{C}$ followed by distilled water rinses. The sections were incubated with Super Block (ScyTek, Logan, UT, U.S.A.) for 5 min and rinsed twice for $5 \mathrm{~min}$ each in buffer (Optimax buffer, Biogenex, San Ramon, CA, U.S.A.). The sections were incubated at $4^{\circ} \mathrm{C}$ overnight in the primary antiserum (1:50). Sections were rinsed with buffer and incubated with UltraTek AntiPolyvalent secondary antibody (ScyTek) for $20 \mathrm{~min}$. The sections were rinsed twice for 5 min each in buffer and incubated with UltraTek horseradish peroxidase (ScyTek) for $20 \mathrm{~min}$ at room temperature. The sections were rinsed twice for $10 \mathrm{~min}$ in buffer and incubated in chromagen (Dako High Sensitivity Chromagen System, DAKO Corporation, Carpinte-

Table 1. Oligonucleotide primer and probe sequences used for real-time PCR for the $E T_{A}$ and $E T_{B}$ receptor

\begin{tabular}{|c|c|c|}
\hline Gene & Oligonucleotide & Sequence \\
\hline \multirow[t]{3}{*}{$\mathrm{ET}_{\mathrm{A}}$ receptor } & Forward primer & 5'-GGTACAGAGCAGTTGCCTCCT-3' \\
\hline & Reverse primer & 5'-ATGACAAAGCCGATTGCTTC-3' \\
\hline & Probe & 5'-TCGTGTTCAGGGAATCGGGAT-3' \\
\hline \multirow{2}{*}{$\mathrm{ET}_{\mathrm{B}}$ receptor } & Reverse primer & 5'-CTGAGTAGGATGGAGCAAGC-3' \\
\hline & Probe & 5'-ACCACTGACTATAAAGGAAATCGCCTG-3' \\
\hline
\end{tabular}


ria, CA, U.S.A.) for $5 \mathrm{~min}$ at room temperature followed by counterstaining with hematoxylin for $30 \mathrm{~s}$. The sections were rinsed in tap water and placed in $0.2 \%$ ammonia for $15 \mathrm{~s}$. The sections were rinsed in tap water followed by polymerization with Crystal Mount (Biomeda, Foster City, CA, U.S.A.), coverslipped with Permount (Fisher Scientific, Fairlawn, NJ, U.S.A.), and then visualized using standard light microscopy.

Data analysis. In statistical analysis and data presentation, $n$ refers to the number of subjects in which observations were made. Data are expressed as means \pm SEM. Statistical comparisons were made by a one-way ANOVA. Tukey-Kramer multiple comparison tests were carried out on data sets in which the $F$ statistic was significant $(p<0.01)$ to determine the sites of significant differences between variables. A $p$ value of $<0.05$ was considered statistically significant.

\section{RESULTS}

Western blot analysis. Western blot analysis was performed to determine whether the degree of protein expression of the $\mathrm{ET}_{\mathrm{A}}$ and $\mathrm{ET}_{\mathrm{B}}$ receptor differed between age groups. $\mathrm{ET}_{\mathrm{A}}$ and $\mathrm{ET}_{\mathrm{B}}$ receptor protein expression in the swine mesenteric artery decreased over the age range studied; thus, $\mathrm{ET}_{\mathrm{A}}$ and $\mathrm{ET}_{\mathrm{B}}$ receptor protein expression was significantly greater in the 3-d-old group then progressively declined over the first post- natal month (Fig. 1). $\beta$-actin expression did not change over the age range studied (Fig. 1).

Partial clone of the swine $\boldsymbol{E T}_{\boldsymbol{B}}$ receptor. Because the cDNA sequence for the swine $\mathrm{ET}_{\mathrm{B}}$ receptor has not been reported, it was necessary to clone this sequence to design primers and a probe for real-time PCR for the $\mathrm{ET}_{\mathrm{B}}$ receptor. Thus, a 552-bp partial clone of the swine $\mathrm{ET}_{\mathrm{B}}$ receptor cDNA was cloned and sequenced (Fig. 2). Based on the reported cDNA sequences from other mammalian species, this sequence corresponds to exons 3-6 for the $\mathrm{ET}_{\mathrm{B}}$ receptor and shares $91 \%, 87 \%$, and $87 \%$ sequence homology with the published human, rat, and mouse $\mathrm{ET}_{\mathrm{B}}$ cDNA sequences, respectively. The deduced amino acid sequence from the partial swine $\mathrm{ET}_{\mathrm{B}}$ cDNA showed 94\%, $91 \%$, and $91 \%$ sequence homology with the published human, rat, and mouse $\mathrm{ET}_{\mathrm{B}}$ amino acid sequences, respectively (Fig. 3).

Real-time PCR. Real-time PCR for the $\mathrm{ET}_{\mathrm{A}}$ and $\mathrm{ET}_{\mathrm{B}}$ receptors was performed to determine whether the increased level of $\mathrm{ET}_{\mathrm{A}}$ and $\mathrm{ET}_{\mathrm{B}}$ protein expression noted in younger subjects with Western blotting was associated with an increased rate of mRNA transcription. $\mathrm{ET}_{\mathrm{A}}$ and $\mathrm{ET}_{\mathrm{B}}$ receptor mRNA expression in the swine mesenteric artery mirrored the Western data; thus, $\mathrm{ET}_{\mathrm{A}}$ and $\mathrm{ET}_{\mathrm{B}}$ receptor mRNA expression was significantly greater in the 3-d-old group then progressively declined over

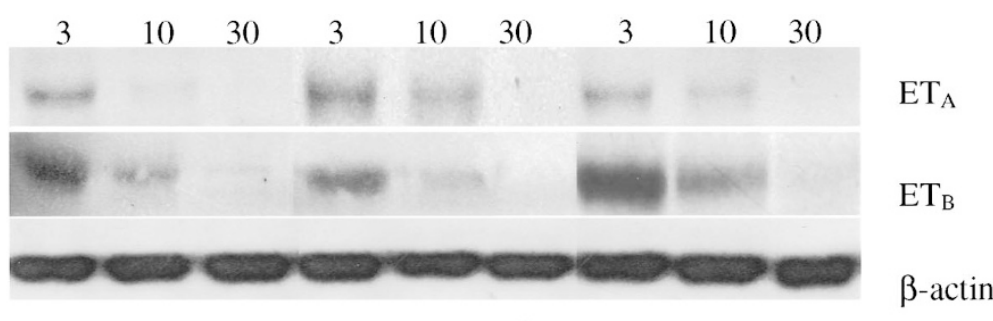

$\mathrm{ET}_{\mathrm{A}}$

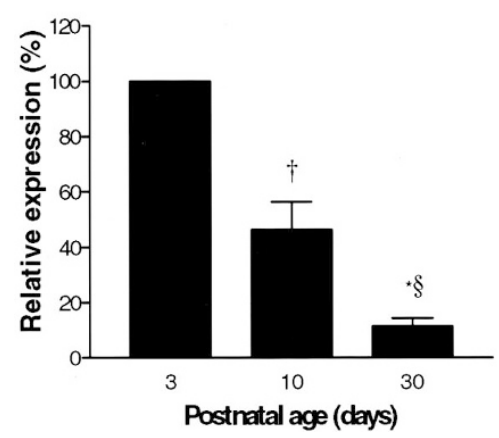

$\mathrm{ET}_{\mathrm{B}}$

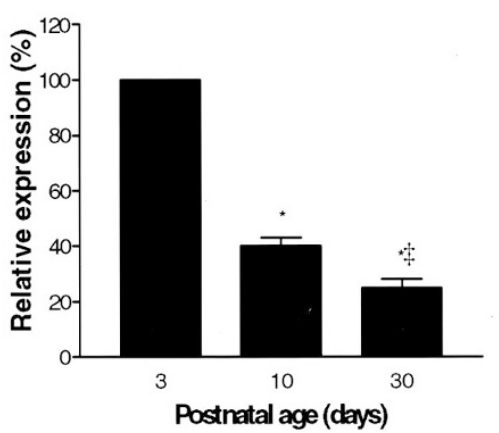

$\beta$-actin

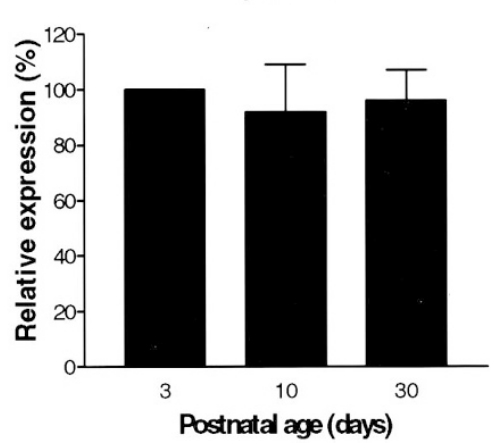

Figure 1. Western blots and densitometry data for $\mathrm{ET}_{\mathrm{A}}$ receptor, $\mathrm{ET}_{\mathrm{B}}$ receptor, and $\beta$-actin expression in 3-, 10-, and 30-d-old subjects. Densitometry was carried out on the individual blots generated for each age group for the $\mathrm{ET}_{\mathrm{A}}$ receptor and $\mathrm{ET}_{\mathrm{B}}$ receptor. Expression of $\mathrm{ET}_{\mathrm{A}}$ receptor and $\mathrm{ET}_{\mathrm{B}}$ receptor was normalized to the 3-d-old group and the relative expression then calculated. The membrane was first incubated with $1^{\circ}$ antibody to either the $\mathrm{ET}_{\mathrm{A}}$ receptor or $\mathrm{ET}_{\mathrm{B}}$ receptor, then stripped and incubated with $1^{\circ}$ antibody to $\beta$-actin to correct for sample loading. Data are given as means \pm SEM, $n=4$ for each experimental group; ${ }^{*} p<0.001$ vs 3-d-old, $\dagger p<0.01$ vs 3-d-old, $\ddagger p<0.01$ vs 10-d-old, $\S p<0.05$ vs 10-d-old. 
CAAAATGGACAGCAGTAGAAATTGTTTTAATTTGGGTGGTCTCCGTGGTCCTGGCCGTCC CGGAAGCCTTGGTTTTGACATGATTACCACTGACTAT $\triangle A \Lambda G G A M A T C G C C T G C G A A T C T$ AGCTTGCTCCATCCTACTCAGAAAACAGCCTTCATGCAGTTTTACAAGACAGCTAAAGTTGO TGGCTATTCAGTTTCTATTTCTGCTTGCCACTAGCCATCACTGCATTTTTTTATACCCCGATGA CCTGTGAAATGCTGAGAAAGAAGAGTGGCATGCAAATTGCTTTAAATGATCACTTAAAGCAG CCTGTG $\triangle A A T G C T G A G A \Lambda A G A A G A G T G G C A T G C A A A T T G C T T T A A A T G A T C A C T T A A A G C A$
AGACGGGAAGTGGCCAGAACCGTATTTTGCTGGTCCTGTCTITGCCCTGTGTTGGCTTCC CCTTCAICTCAGCAGGAl"TTTGAAGCTCACTCTGTATGATCAAAATGATTCGAATAGATG'GA ACTTTTGAGCTTTTTGTTGGTATTGGATTACATTGGCATCAACATGGCGTCCCTGAATTCCTG TATTAATCCAATAGCTCTGTATTTGGTGAGCAAAAGATTCAAAAACTGCTTTAAGTC

Figure 2. Partial cDNA sequence for the swine $\mathrm{ET}_{\mathrm{B}}$ receptor. A 552-bp cDNA fragment corresponding to exons 3-6 of the $\mathrm{ET}_{\mathrm{B}}$ receptor was cloned and sequenced as described in the text (GenBank accession number AY583500). The underlined sequences represent the primers and probe used for real-time PCR.

Swine FDMITTDYKGNRLRICLLHPTQKTAFMQFYKTAKDWWLFSFYFCLPLAITAFFYTPMTCE

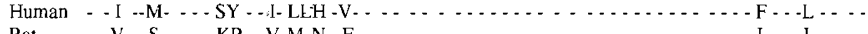
Rat - - V - -S - - - KP - -V-M-N - F - . . . - . . . . . . .

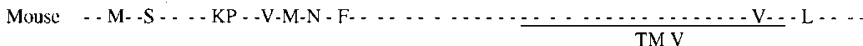

Swine MLRKKSGMQIALNDHLKQRREVARTVFCLVLVFALCWLPLHLSRILKLTLYDQNDSNRC

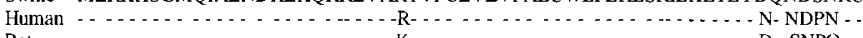

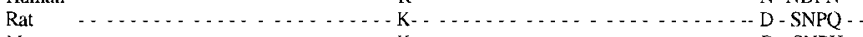

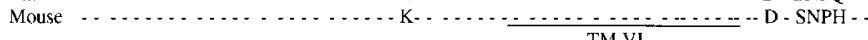

Swine ELLSFLLVLDYIGINMASLNSCINPIALYLVSKRFKNCFK

Human...$\ldots \ldots \ldots \ldots \ldots$

Rat

Mouse $\frac{\text { TM VII }}{\text { Rat }}$

Figure 3. Comparison of the amino acid sequences between the swine, human, rat, and mouse $\mathrm{ET}_{\mathrm{B}}$ receptor. The deduced amino acid sequence from the partial cDNA for the swine $\mathrm{ET}_{\mathrm{B}}$ receptor was compared with the published amino acid sequences for the human, rat, and mouse $\mathrm{ET}_{\mathrm{B}}$ receptor. The sequence contains three transmembrane domains, V-VII (underlined), and the third cytoplasmic loop between TM V and VI.

the first postnatal month (Fig. 4). 18S ribosomal RNA expression did not change over the age range studied (data not shown).

Immunohistochemistry. Immunohistochemistry was performed to localize the $\mathrm{ET}_{\mathrm{A}}$ and $\mathrm{ET}_{\mathrm{B}}$ receptors within the superior mesenteric artery in 3-, 10-, and 30-d old subjects. The $\mathrm{ET}_{\mathrm{A}}$ receptor was localized to the vascular smooth muscle, whereas the $\mathrm{ET}_{\mathrm{B}}$ receptor was localized in the endothelial layer in a 3-d-old subject (Fig. 5). A similar pattern was noted in superior mesenteric arteries harvested from 10- and 30-d-old subjects (data not shown).

\section{DISCUSSION}

The novel observation made in this study is that expression of endothelin $\mathrm{ET}_{\mathrm{A}}$ and $\mathrm{ET}_{\mathrm{B}}$ receptors within the swine mesenteric artery is developmentally regulated during early postnatal life. This developmental regulation occurred at the level of gene transcription inasmuch as the changes in protein expression noted on Western analysis paralleled the changes in mRNA expression noted by real-time PCR. Immunohistochemistry localized the $\mathrm{ET}_{\mathrm{A}}$ receptor to the vascular smooth muscle and the $\mathrm{ET}_{\mathrm{B}}$ receptor to the endothelial cell layer. Additionally, we report a partial cDNA sequence for the swine $\mathrm{ET}_{\mathrm{B}}$ receptor.

The developmental changes noted in $\mathrm{ET}_{\mathrm{A}}$ and $\mathrm{ET}_{\mathrm{B}}$ expression are consistent with prior observations reported from this laboratory. Studies within blood-perfused, innervated in situ gut loops (13), in mesenteric artery rings suspended for tension measurement (14), and in buffer-perfused terminal mesenteric
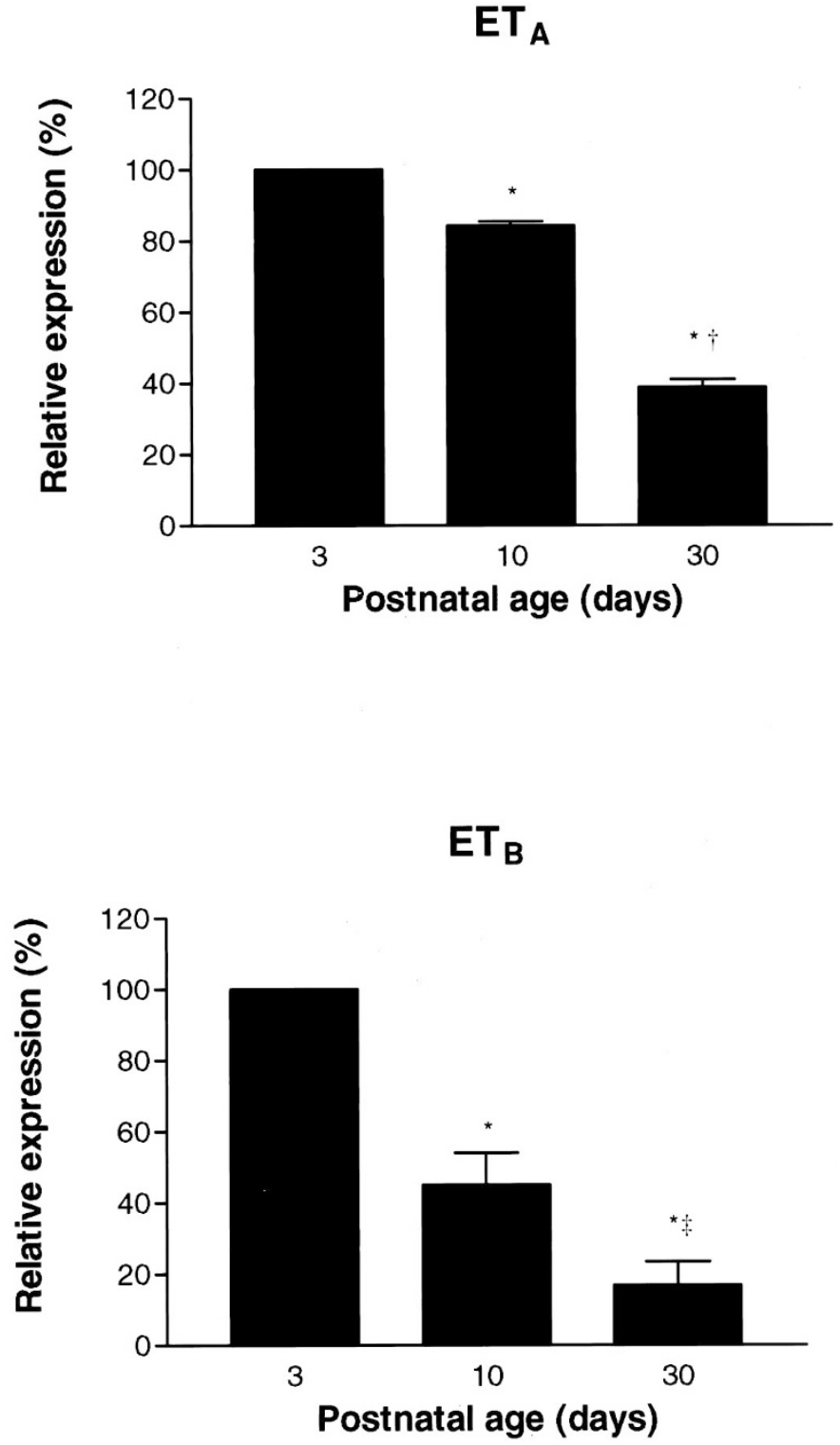

Figure 4. Real-time $\mathrm{PCR}$ detection of $\mathrm{ET}_{\mathrm{A}}$ receptor and $\mathrm{ET}_{\mathrm{B}}$ receptor expression levels in 3-, 10-, and 30-d-old subjects. The $\mathrm{C}_{\mathrm{t}}$ values obtained for the internal control (18S ribosomal RNA) were subtracted from the $C_{t}$ values obtained for the target gene mRNA in question $\left(\mathrm{ET}_{\mathrm{A}}\right.$ or $\left.\mathrm{ET}_{\mathrm{B}}\right)$, normalized to the 3-d-old group, and the relative expression was then calculated. Data are given as means $\pm \mathrm{SEM}, n=4-6$ for each experimental group; $* p<0.01 v \mathrm{~s}$ 3-d-old, $\uparrow p<0.001$ vs 10-d-old, $\ddagger p<0.05$ vs 10-d-old.

arterioles mounted within a microvascular chamber (21) have all provided physiologic evidence that $\mathrm{ET}_{\mathrm{B}}$ receptors are present in greater abundance in newborn (i.e., 3-d-old) intestine. Thus, selective blockade of $\mathrm{ET}_{\mathrm{B}}$ receptors with $\mathrm{BQ788}$ resulted in a leftward shift in the contractile dose-response curve for ET-1 in intestine or mesenteric artery from 3-d-old but not 35-d-old subjects, whereas the administration of the selective $\mathrm{ET}_{\mathrm{B}}$ receptor agonist sarafotoxin $6 \mathrm{c}$ to precontracted preparations caused vasodilation only in preparations from 3 -d-old subjects $(14,21)$. These observations are each consistent with the presence of an abundant endothelial $\mathrm{ET}_{\mathrm{B}}$ receptor population within the newborn intestinal circulation whose activation leads to vasodilation. Physiologic evidence for an 

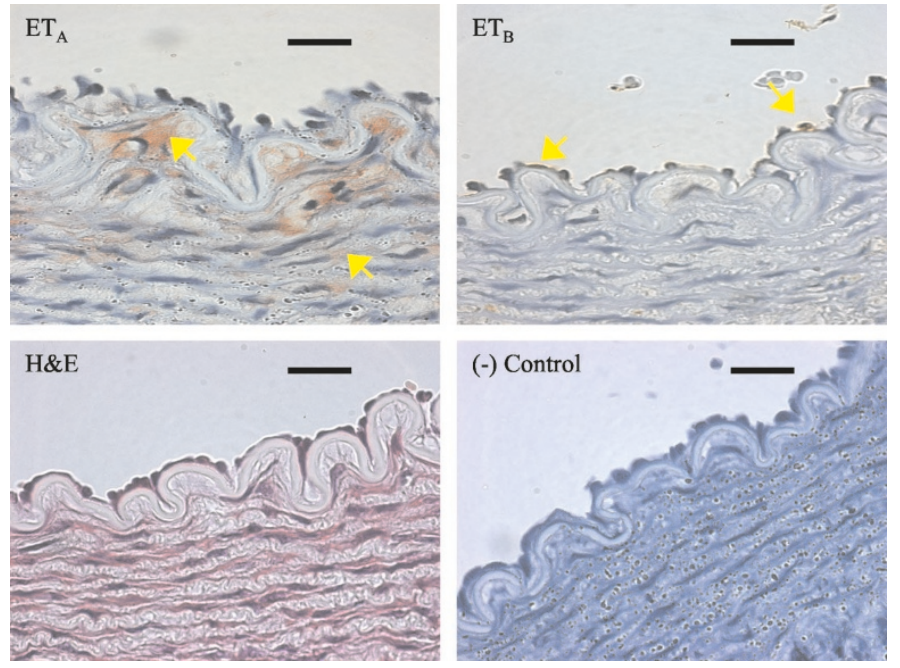

Figure 5. Immunohistochemical localization of $\mathrm{ET}_{\mathrm{A}}$ receptors and $\mathrm{ET}_{\mathrm{B}}$ receptors in a 3-d-old subject. Representative photomicrograph $(1000 \times)$ of immunohistochemical staining for the $\mathrm{ET}_{\mathrm{A}}$ and $\mathrm{ET}_{\mathrm{B}}$ receptors in the superior mesenteric artery from a 3-d-old subject. Note the localization of the $\mathrm{ET}_{\mathrm{A}}$ receptor to the vascular smooth muscle (upper left panel), and the $\mathrm{ET}_{\mathrm{B}}$ receptor to the endothelial cell layer (upper right panel). A hematoxylin-and-eosinstained control section is presented for comparison (lower left panel). Additionally, a negative control section (without primary antibody) is presented to verify the specificity of the $\mathrm{ET}_{\mathrm{A}}$ and $\mathrm{ET}_{\mathrm{B}}$ antisera used (lower right panel). Immunohistochemical staining in 10- and 30-d-old subjects demonstrated a similar pattern for the $\mathrm{ET}_{\mathrm{A}}$ and $\mathrm{ET}_{\mathrm{B}}$ receptors. Scale bars in each photomicrograph represent $20 \mu \mathrm{m}$.

increased level of $\mathrm{ET}_{\mathrm{A}}$ receptor expression in newborn intestine also exists; thus, selective blockade of the $\mathrm{ET}_{\mathrm{A}}$ receptor within in situ newborn intestine leads to an increase in the perfused capillary density and enhanced oxygen extraction in 3 -d-old but not 35-d-old intestine, suggesting that the precapillary sphincters that govern capillary perfusion (22) are under tonic control of ET-1 in newborn intestine (13). The endothelial localization of this age-specific $\mathrm{ET}_{\mathrm{B}}$ receptor expression was demonstrated by studies in which the endothelium was mechanically removed $(14,16)$. We have further shown that ligand binding to these endothelial $\mathrm{ET}_{\mathrm{B}}$ receptors caused an NO-mediated vasodilation (14). Thus, the newborn intestine has a relative abundance of contractile $\mathrm{ET}_{\mathrm{A}}$ receptors located on vascular smooth muscle, but also has a large population of vasodilatory $\mathrm{ET}_{\mathrm{B}}$ receptors located on the vascular endothelium.

The present data do not provide insight into the reason for the increased expression of $\mathrm{ET}_{\mathrm{A}}$ and $\mathrm{ET}_{\mathrm{B}}$ receptors in newborn intestine; however, some speculation that is based on the established roles for the ET-1 peptide might be relevant. ET-1 is the most potent vasoconstrictor substance discovered to date (1) and there is a substantial body of evidence that the contractile capacity of this peptide plays an important role in cardiovascular regulation, especially on a systemic scale (23, 24). ET-1 is also an exceptionally potent mitogenic factor and has been shown to stimulate DNA synthesis and cell proliferation in a variety of cells including fibroblasts and endothelial and vascular smooth muscle cells largely via stimulation of $\mathrm{ET}_{\mathrm{A}}$ receptors (25-30). ET-1 may also play an important role in the process of angiogenesis by interacting with known angiogenic factors such as vascular endothelial growth factor and platelet-derived growth factor to regulate endothelial cell activity, again via interaction with the $\mathrm{ET}_{\mathrm{A}}$ receptor $(31,32)$. The newborn intestine is the site of intense growth during early postnatal life (17) as it transitions from relative dormancy in utero to become the sole means of water and nutrient assimilation after birth. Part of this growth process involves angiogenesis; thus, it is not surprising that the $\mathrm{ET}_{\mathrm{A}}$ receptor is substantially expressed in newborn intestine or that the concentration of ET-1 in the mesenteric venous effluent is greater in newborn subjects (13). It seems logical that an enhanced expression of endothelial $\mathrm{ET}_{\mathrm{B}}$ receptors is also present at this time to offset the potential vasoconstrictor effect of an abundance of $\mathrm{ET}_{\mathrm{A}}$ receptors and ET-1. Thus, we speculate that this developmental expression of the ET receptor system is designed to facilitate the role of ET-1 in intestinal growth and angiogenesis in the postnatal newborn intestine without causing undue vasoconstriction.

The $\mathrm{ET}_{\mathrm{B}}$ receptor, like the $\mathrm{ET}_{\mathrm{A}}$ receptor, is a member of the seven-transmembrane-spanning, $G$ protein-coupled superfamily of receptors whose stimulation leads to the activation of multiple effector pathways (33). The cDNA sequence for the $\mathrm{ET}_{\mathrm{B}}$ receptor has been reported in several mammalian species including the human, rat, and mouse (34-36); however, the cDNA sequence for the swine $\mathrm{ET}_{\mathrm{B}}$ receptor has not been previously reported. The partial cDNA sequence and deduced amino acid sequence for the swine $\mathrm{ET}_{\mathrm{B}}$ receptor reported here shares significant sequence homology with other mammalian species and codes for transmembrane domains V-VII, which contains the highly conserved third cytoplasmic loop between transmembrane domains V and VI.

We conclude that, within the swine mesenteric artery, expression of endothelin $\mathrm{ET}_{\mathrm{A}}$ and $\mathrm{ET}_{\mathrm{B}}$ receptors is developmentally regulated during early postnatal life. This developmental regulation of $\mathrm{ET}_{\mathrm{A}}$ and $\mathrm{ET}_{\mathrm{B}}$ receptor expression occurs at the level of gene transcription, although the mechanisms involved were not established by the current work. However, we speculate that these mechanisms may be closely coupled with the maturation of the intestine and its attendant vasculature, and may play important roles in gut development during early postnatal life.

Acknowledgments. The authors thank Florinda Jaynes for technical support, Dr. Philip Nowicki for critical review of the manuscript, and Karen Watkins for secretarial support.

\section{REFERENCES}

1. Yanagisawa M, Kurihara H, Kimura S, Tomobe Y, Kobayashi M 1988 A novel potent vasoconstrictor peptide produced by the vascular endothelium. Nature 332:411-413

2. Arai H, Hori S, Aramori I, Ohkubo H, Nakanishi S 1990 Cloning and expression of a cDNA encoding an endothelin receptor. Nature 348:730-732

3. Ihara M, Ishikawa K, Fukuroda T, Saeki T, Funabashi K, Fukami T, Suda H, Yano M 1992 In vitro biological profile of a highly potent novel endothelin (ET) antagonist BQ-123 selective for the ETA receptor. J Cardiovasc Pharmacol 12:1-4

4. Sakurai T, Yanagisawa M, Takuwa Y, Miyazaki H, Kimura S, Goto K, Masaki T 1990 Cloning of a cDNA encoding a non-isopeptide-selective subtype of the endothelin receptor. Nature 348:732-735

5. Tsukahara H, Ende H, Magazine H, Bahou W, Goligorsky M 1994 Molecular and functional characterization of the non-isopeptide-selective ETB receptor in endothelial cells: receptor coupling to nitric oxide synthase. J Biol Chem 269:21778-21785 
6. Takigawa M, Sakuri T, Kasuya Y, Abe Y, Masaki T, Goto K 1995 Molecular identification of guanine-nucleotide-binding proteins which couple to endothelin receptors. Eur J Biochem 228:102-108

7. Takuwa Y, Kasuya Y, Takuwa N, Kudo M, Yanagisawa M, Goto K, Masaki T, Yamashita K 1990 Endothelin receptor is coupled to phospholipase C via a pertussis toxin-insensitive guanine nucleotide-binding regulatory protein in vascular smooth muscle cells. J Clin Invest 85:653-658

8. Clozel M 1989 Specific binding of ET on human vascular smooth muscle cells in culture. J Clin Invest 83:1758-1762

9. Davenport A, O'Reilly G, Kuc R 1995 Endothelin $\mathrm{ET}_{\mathrm{A}}$ and $\mathrm{ET}_{\mathrm{B}}$ mRNA and receptors expressed by smooth muscle in the human vasculature: majority of the $\mathrm{ET}_{\mathrm{A}}$ subtype. Br J Pharmacol 114:1100-1105

10. De Nucci G, Thomas R, D'Orleans-Juste P, Antunes E, Walker C, Warner TD, Vane JR 1988 Pressor effects of circulating endothelin are limited by its removal in the pulmonary circulation and by the release of prostacyclin and endothelium-derived relaxing factor. Proc Natl Acad Sci U S A 85:9797-9800

11. Takayanagi R, Kitazumi K, Takasaki C, Ohnkada K, Aimoto S, Tasaka K, Ohashi M, Nawata H 1991 Presence of non-selective type of endothelin receptor on vascular endothelium and its linkage to vasodilation. FEBS Lett 282:103-106

12. Bacon CR, Davenport AP 1998 Endothelin receptors in human coronary artery and aorta. Br J Pharmacol 117:986-992

13. Nankervis CA, Nowicki PT 2000 Role of endothelin-1 in regulation of the postnatal intestinal circulation. Am J Physiol 278:G367-G375

14. Nankervis CA, Schauer GM, Miller CE 2000 Endothelin mediated vasoconstriction in postischemic newborn intestine. Am J Physiol 279:G683-G691

15. Williams D, Jones K, Pettibone D, Lis E, Clineschmidt B 1991 Sarafotoxin S6c: an agonist which distinguishes between endothelin receptor subtypes. Biochem Biophys Res Commun 175:556-561

16. Nankervis CA, Dunaway D, Miller C 2001 Endothelin $\mathrm{ET}_{\mathrm{A}}$ and $\mathrm{ET}_{\mathrm{B}}$ receptors in postnatal intestine. Am J Physiol 280:G555-G562

17. Widdowson E, Colombo V, Artavanis C 1976 Changes in the organs of pigs in response to feeding for the first $24 \mathrm{~h}$ after birth. II. The digestive tract. Biol Neonate 28:272-281

18. Douglas W 1971 Of pigs and men and research: a review of the applications of the pig, Sus scrofa in human medical research. Space Life Sci 3:226-234

19. Stanton H, Mersmann H1986 Swine in Cardiovascular Research. CRC Press, Boca Raton, FL, pp 1-33

20. Smith PJW, Brooks JI, Stewart DJ, Monge JC 1999 Quantification of endothelin ETA and ETB receptor mRNA by competitive reverse transcription-polymerase chain reaction: development of a multispecies assay. Anal Biochem 271:93-96

21. Nankervis CA, Dunaway D, Nowicki P 2001 Determinants of terminal mesenteric artery resistance during the first postnatal month. Am J Physiol 280:G678-G686

22. Granger DN, Kvietys PR, Perry MA 1982 Role of exchange vessels in the regulation of intestinal oxygenation. Am J Physiol 242:G570-G574
23. Wright CE, Fozard JR 1988 Regional vasodilation is a prominent feature of the haemodynamic response to endothelin in anaesthetized, spontaneously hypertensive rats. Eur J Pharmacol 155:201-203

24. Le Monnier De Gouville A-C, Lippton HL, Cavero I, Summer WR, Hyman AL 1989 Endothelin - a new family of endothelin-derived peptides with widespread biological properties. Life Sci 45:1499-1513

25. Chiou WJ, Wang J, Berg CE, Wu-Wong JR 1999 SV40 virus transformation down-regulates endothelin receptor. Biochim Biophys Acta 1450:35-44

26. Morbidelli L, Orlando C, Maggi CA, Ledda F, Ziche M 1995 Proliferation and migration of endothelial cells is promoted by endothelins via activation of $\mathrm{ET}_{\mathrm{B}}$ receptors. Am J Physiol 269:H686-H695

27. Yoshizumi M, Kim S, Kagami S, Hamaguchi A, Tsuchiya K, Houchi H, Iwao, Kido H, Tamaki T 1998 Effect of endothelin-1 (1-31) on extracellular signal-regulated kinase and proliferation of human coronary artery smooth muscle cells. Br J Pharmacol 125:1019-1027

28. Hafizi S, Allen SP, Goodwin AT, Chester AH, Yacoub MH 1999 Endothelin-1 stimulates proliferation of human coronary smooth muscle cells via the ET(A) receptor and is co-mitogenic with growth factors. Atherosclerosis 146:351-359

29. Ohlstein EH, Arleth A, Bryan H, Elliott JD, Sung CP 1992 The selective endothelin $\mathrm{ET}_{\mathrm{A}}$ receptor antagonist BQ123 antagonizes endothelin-1-mediated mitogenesis. Eur J Pharmacol 225:347-350

30. Panettieri RA, Goldie RG, Rigby PJ, Eszterhas AJ, Hay DW 1996 Endothelin-1induced potentiation of human airway smooth muscle proliferation: an ETA receptormediated phenomenon. Br J Pharmacol 118:191-197

31. Matsuura A, Yamochi W, Hirata K, Kawashima S, Yokoyama M 1998 Stimulatory interaction between vascular endothelial growth factor and endothelin-1 on each gene expression. Hypertension 32:89-95

32. Assender JW, Irenius E, Fredholm BB 1996 Endothelin-1 causes a prolonged protein kinase $\mathrm{C}$ activation and acts as a co-mitogen in vascular smooth muscle cells. Acta Physiol Scand 157:451-460

33. Sakuri T, Yanagisawa M, Takuwa Y, Miyazaki H, Kimura S, Goto K, Masaki T 1990 Cloning of a cDNA encoding a non-isopeptide-selective subtype of the endothelin receptor. Nature 348:732-735

34. Elshourbagy NA, Korman DR, Wu HL, Sylvester DR, Lee JA, Nuthalaganti P, Bergsma DJ, Kumar CS, Nambi P 1993 Molecular characterization and regulation of the human endothelin receptors. J Biol Chem 268:3873-3879

35. Leng N, Gu G, Simerly RB, Spindel ER 1999 Molecular cloning and characterization of two putative $\mathrm{G}$ protein-coupled receptors which are highly expressed in the central nervous system. Brain Res Mol Brain Res 69:73-83

36. Kapur RP, Sweetser DA, Doggett B, Siebert JR, Palmiter RD 1995 Intercellular signals downstream of endothelin receptor-B mediate colonization of the large intestine by enteric neuroblasts. Development 121:3787-3795 